\title{
TOXICOLOGICAL ASSESSMENT OF REFINED PALM-PRESSED MESOCARP FIBRE OIL
}

\author{
KIM-TIU TENG ${ }^{1 *}$; RADHIKA LOGANATHAN ${ }^{1}$; EE LING SIEW'2,3; HARRISON LIK NANG LAU \\ and NOR FADILAH RAJAB ${ }^{3,4}$
}

\begin{abstract}
Refined palm-pressed mesocarp fibre oil (PMFO) is a rich source of phytonutrients, which merits further exploration as a functional food component. Current study aimed to evaluate the cytotoxicity and genotoxicity of refined PMFO using MTT [3-(4,5-dimethylthiazol-2-yl)-2,5-diphenyltetrazolium bromide] and alkaline comet assay, respectively. Acute oral toxicity assessment was performed on two groups of rats using a stepwise procedure based on OECD 423. Animals were observed for clinical effects at $30 \mathrm{~min}$, hourly for 4 and $6 \mathrm{hr}$ post dosing and once daily up to day 14 . There were no inhibitory concentration $\left(I C_{50}\right)$ values observed for refined PMFO treated V79-4 Chinese hamster lung cells as compared to positive control hydrogen peroxide $\left(\mathrm{H}_{2} \mathrm{O}_{2}\right)$, where a concentration response effect was seen following treatment with $\mathrm{H}_{2} \mathrm{O}_{2}$ with an $\mathrm{IC}_{50}$ value of $1.568 \mathrm{mM}$. Refined PMFO has no capability to induce direct deoxyribonucleic acid (DNA) strand breakage in V79-4 cells. In addition, refined PMFO showed no-observed-adverse-effect level (NOAEL) up to $2000 \mathrm{mg} / \mathrm{kg}$ body weight of the animal. Taken together, our study suggests that refined PMFO has great potential to be used in functional applications such as in food, dietary supplements and pharmaceutical products.
\end{abstract}

Keywords: acute oral toxicity, cytotoxicity, DNA damage, genotoxicity, palm-pressed mesocarp fibre oil.

Received: 15 March 2021; Accepted: 30 November 2021; Published online: 31 January 2022.

\section{INTRODUCTION}

Palm-pressed mesocarp fibre oil (PMFO) is a residual oil extracted from palm-pressed mesocarp

1 Malaysian Palm Oil Board,

6 Persiaran Institusi, Bandar Baru Bangi,

43000 Kajang, Selangor, Malaysia.

2 ASASI Pintar Unit, Pusat GENIUS@Pintar Negara, Universiti Kebangsaan Malaysia,

43600 Bangi, Selangor, Malaysia.

3 Biocompatibility and Toxicology Laboratory, Centre for Research and Instrumentation Management (CRIM), Universiti Kebangsaan Malaysia, 43600 Bangi, Selangor, Malaysia.

4 Center for Healthy Aging and Wellness Faculty of Health Sciences, Universiti Kebangsaan Malaysia, Kuala Lumpur, Malaysia.

* Corresponding author e-mail: kimtiu@mpob.gov.my fibre, a by-product obtained from palm oil milling process. Crude palm oil (CPO) is typically recovered from the mesocarp of palm fruits by dry method using hydraulic press or a screw press (Obibuzor et al., 2012). Following this process, 5\%-6\% of oil still remains as a ratio to the dry matter of mesocarp fibre (Obibuzor et al., 2012). This residual oil can be recovered by several methods e.g. solvent extraction (Neoh et al., 2011), supercritical carbon dioxide extraction (Lau et al., 2006; Putra et al., 2019), enzymatic reaction (Noorshamsiana et al., 2017), soxhlet method (Neoh et al., 2011; Putra et al., 2019), reflux method (Neoh et al., 2011) and residual oil recovery system (Subramaniam et al., 2013). The valuable phytonutrients in the residual oil are urged to be recovered before subjecting the mesocarp fibre as energy source for palm oil mills (Choo et al., 1996).

The PMFO is richer in phytonutrients as compared to CPO (Teh and Lau, 2021). Refined PMFO was extracted from pressed mesocarp using 
n-hexane while CPO was obtained by mechanical pressing of mesocarp. A significant quantity of carotenes (1716-2083 ppm), tocols (900-1200 ppm) (Abd Majid et al., 2012), sterols (4509-8490 ppm) (Choo et al., 1996) and squalene (1117-9690 ppm) (Lau et al., 2008) remain in the residual oil of PMFO as compared to CPO. Inferior to PMFO, CPO contains 599-619 ppm of carotenes, $600-800$ ppm of tocols (Abd Majid et al., 2012), 250-620 ppm sterols (Choo et al., 1996) and squalene (250-540 ppm) (Loganathan et al., 2010). The tocols composition also differs between PMFO (54\% of $\alpha$-tocopherol, $19 \%$ of $\alpha$-tocotrienol, $17 \%$ of $\gamma$-tocotrienol, and $10 \%$ of $\delta$-tocotrienol) and CPO (21\% of $\alpha$-tocopherol, $25 \%$ of $\beta$-tocotrienol, $37 \%$ of $\gamma$-tocotrienol, and $17 \%$ of $\delta$-tocotrienol) (Abd Majid et al., 2012). Ninety percent of carotenoids found in $\mathrm{CPO}$ are in the form of $\alpha$ - and $\beta$-carotenes (35\% and $56 \%$, respectively) (Choo et al., 1996). In the case of PMFO, $\alpha$ - and $\beta$-carotenes only constitute to $50 \%$ (19\% and $31 \%$, respectively). Interestingly, higher amounts of lycopene $(14.1 \%)$, phytoene $(11.9 \%), \delta$-carotene $(7.6 \%), \delta$-carotene $(6.9 \%)$, neurosporene $(3.38 \%)$, and $\gamma$-carotene $(2.7 \%)$ are found in PMFO as compared to CPO (Choo et al., 1996). In terms of sterols, both PMFO and $\mathrm{CPO}$ have similar compositional profile of $\beta$-sitosterol (56\%-59\%), campesterol (19\%-22\%) and stigmasterol (18\%-20\%) (Choo et al., 1996).

Both the PMFO and CPO contains predominantly palmitic acid (PMFO: $30.9 \%-32.6 \%$, CPO: $39.5 \%-39.8 \%$ ) and oleic acid (PPFO: $24.5 \%-$ $25.1 \%$, CPO: $35.6 \%-38.7 \%$ ). PMFO is unique as it is rich in medium chain triglyceride namely lauric acid $(20.0 \%-23.6 \%)$ which is trace in CPO (0.2\%-0.3\%) (Abd Majid et al., 2012). The presence of lauric acid in PMFO is due to broken kernels trapped in mesocarp fibre (Abd Majid et al., 2012; Sulihatimarsyila et al., 2019).

To date, there is no scientific evidence on the safety assessment of PMFO nor refined PMFO. There is a recent publication on the blending of PMFO with CPO on oil quality and nutritional profile (Hasliyati et al., 2021), yet toxicological aspects have not been investigated. Although chemically refined PMFO is proven to be safe for food application (Sulihatimarsyila et al., 2019), however there is no biological evidence to support this claim. Hence, there exists a necessity to study the toxicity aspects of refined PMFO to further exploit their functional applications in food, dietary supplements and pharmaceutical. Thus, the present study was designed to examine the safety assessment of refined PMFO based on its toxicological potential using both cell culture and animal acute study models. The terms of refined PMFO or PMFO are used throughout the manuscript to indicate the difference between refined PMFO and PMFO.

\section{MATERIALS AND METHODS}

\section{Materials}

The refined PMFO used in the current study was refined according to the published method as described by Sulihatimarsyila et al. (2019; 2020). The optimum conditions for the refining process comprised of water degumming using $5.0 \mathrm{v} / \mathrm{v} \%$ of water at $90^{\circ} \mathrm{C}$, followed by acid degumming using 1.0 weight $\%$ of phosphoric acid at $90^{\circ} \mathrm{C}$, bleaching using 0.1 weight $\%$ of natural bleaching earth at $105^{\circ} \mathrm{C}$ and deacidification at $110^{\circ} \mathrm{C}$ at 0.1 mtorr (Lau et al., 2006). The refined PMFO was supplied by Kim Loong Palm Oil Mills Sdn. Bhd., Johor, Malaysia.

\section{Cell Line, Standards, Chemicals and Reagents}

V79-4 Chinese hamster lung cells (Cricetulus griseus fibroblast, CCL-93TM) were purchased from the American Type Culture Collection (ATCC) (Montgomery, USA). Myristic acid (14:0), palmitic acid (16:0), stearic acid (18:0), and oleic acid (18:1); monopalmitin, monostearin, and monoolein; 1,2and 1,3-dipalmitin, 1,2- and 1,3-distearin, and 1,2- and 1,3-diolein; tripalmitin and squalene; $\beta$-sitosterol, campesterol, stigmasterol, and cholesterol; low melting points agarose (LMA) and normal melting point agarose (NMA); acetone, uranyl acetate, hydrogen peroxide $\left(\mathrm{H}_{2} \mathrm{O}_{2}\right)$, ethidium bromide solution and 3-(4,5-dimethylthiazol-2-yl)2,5-diphenyltetrazolium bromide (MTT) reagent were obtained from Sigma Aldrich (Montgomery, USA). Dubelcco Modified Eagle Media (DMEM), fetal bovine serum (FBS), penicillin-streptomycin, glutaraldehyde, and phosphate buffer saline were purchased from Gibco- Thermo Fisher Scientific, Inc. (England, United Kingdom). The silylating reagent $\mathrm{N}, \mathrm{O}$-bis(trimethylsilyl) trifluoroacetamide with $1 \%$ trimethylchlorosilane (BSTFA) was purchased from Fluka Chemicals (Buchs, Switzerland). All solvents were purchased from Merck and were of chromatographic or analytical grade. A TLC plate coated with silica gel 60 F254 $(20 \times 20 \mathrm{~cm}$; Merck 1.05715.0001) was obtained from Merck (Darmstadt, Germany).

\section{Cell Culture}

The Chinese hamster lung V79-4 fibroblast cells were cultured in DMEM supplemented with $10 \%$ FBS and maintained at $37^{\circ} \mathrm{C}$ in a $5 \%$ carbon dioxide $\left(\mathrm{CO}_{2}\right)$ incubator. After reaching confluency, cells were detached via trypsinisation $(0.025 \%$ trypsin $)$.

\section{Preparation of Compound and Evaluation of Physical Characteristics}

Refined PMFO was first dissolved in dimethyl 
sulphoxide (DMSO) at a concentration of 50\%. The solution was further diluted in DMEM to $1 \%(\mathrm{v} / \mathrm{v})$ of concentration as working solution. Total carotene content in the oil sample was analysed using a UV-Vis Spectrometer, model U-2001 (Hitachi Instruments Inc., Tokyo, Japan) according to MPOB Test Method p2.6:2004 (Ainie et al., 2005). Free fatty acid (FFA), monoacylglycerols (MAG), diacylglycerols (DAG), triacylglycerols (TAG), sterols and squalene were determined by using a Hewlett-Packard Series II gas chromatography, model 5890 (Hewlett-Packard, Avondale, USA), as described previously (Nang Lau et al., 2005). Vitamin E content was determined by high-performance liquid chromatography with fluorescence detector (Agilent Technologies, Palo Alto, USA) as described previously (Sulihatimarsyila et al., 2019).

\section{MTT Viability Assay}

The cytotoxicity of refined PMFO was determined using MTT assay to assess the amount of formazan crystals formed via a reduction process in the mitochondria (Mosmann, 1983). The cells were seeded in 96-well microplate at $5 \times 10^{4}$ cells / mL (based on established and published data in our laboratory) (Awang et al., 2015; Siew et al., 2020) and were incubated at $37^{\circ} \mathrm{C}$ in $5 \% \mathrm{CO}_{2}$ for $24 \mathrm{hr}$. Media was replaced with treatment medium containing highest concentration of refined PMFO $(1 \% \mathrm{v} / \mathrm{v})$ on the following day and the cells were incubated further for $24 \mathrm{hr}$. Then $30 \mu \mathrm{L}$ of sterile MTT solution $(5 \mathrm{mg} / \mathrm{mL}$ ) was added into each well and the plate was incubated for $4 \mathrm{hr}$. Media and MTT solution were removed after $4 \mathrm{hr}$ and $200 \mu \mathrm{L}$ of DMSO was added into each well to dissolve the formazan crystals. The plate was shaken for $10 \mathrm{~min}$ and the optical density reading of each well was obtained using enzyme-linked immunoassay (ELISA) plate reader at $570 \mathrm{~nm}$ wavelength. Graph of viability was plotted against concentration.

\section{Alkaline Comet Assay}

The genotoxicity of refined PMFO was assessed using the alkaline comet assay by detecting the primary DNA damage (Tice et al., 2000). The V79-4 cells were seeded in 6-well plate were treated with IC10 $[0.162 \%(\mathrm{v} / \mathrm{v})]$ and IC25 [0.45\% (v/v)] following $24 \mathrm{hr}$ of incubation. Cells were also treated with $\mathrm{H}_{2} \mathrm{O}_{2}$ (positive control, $1.0 \mathrm{mM}$ ) for $30 \mathrm{~min}$. Then, the cells were detached, trypsinised and collected for centrifugation at $2500 \mathrm{rpm}$ for $5 \mathrm{~min}$. The supernatant was removed, and the pellet was washed with $\mathrm{Ca}^{2+}-/ \mathrm{Mg}^{2+}$-free PBS prior to re-centrifugation. Pellets left at the bottom were mixed thoroughly with $80 \mathrm{~mL}$ of $0.6 \%$ LMA (w/v) and the mixture was pipetted onto hardened $0.6 \%$
NMA (w/v) on the slide. Cover slips were placed to spread the mixture and the slides were left on ice for LMA to solidify. Following the removal of the cover slips, the embedded cells were lysed in lysis buffer containing $2.5 \mathrm{M}$ sodium chloride $(\mathrm{NaCl}), 100$ $\mathrm{mM} \mathrm{Na}{ }_{2}$ EDTA, $10 \mathrm{mM}$ Tris, and $1 \%$ Triton $\mathrm{X}-100$ for $1 \mathrm{hr}$ at $4^{\circ} \mathrm{C}$. As for DNA-unwinding procedure, slides were soaked in electrophoresis buffer solution for $20 \mathrm{~min}$ at $4^{\circ} \mathrm{C}$ prior to electrophoresis at $300 \mathrm{~mA}$, $25 \mathrm{~V}$, for $20 \mathrm{~min}$. Subsequently, the slides were rinsed with neutralising buffer for $5 \mathrm{~min}$ and stained with $50 \mu \mathrm{L}$ ethidium bromide solution. Slides were left overnight at $4^{\circ} \mathrm{C}$ before analysis with fluorescence microscope (Nikon E600, USA) equipped with 515 barrier filter and 560 emission filter. Tail moment (TM) of 50 cells per slide were scored and analysed using COMET assay III (Perceptive Instruments, United Kingdom).

\section{Acute Oral Toxicity Study}

Acute oral toxicity study was appropriate for the purpose to determine the adverse toxic effect and responses of a test material following oral administration of the test material in rats within a short time period. Hence, the study was performed on two groups of rats using a stepwise procedure. In the first step, three female SpragueDawley rats (Test Group) were administered orally with $2000 \mathrm{mg} / \mathrm{kg}$ body weight of test substance in $10 \mathrm{~mL} / \mathrm{kg}$ vehicle (pre-filtered water). Three additional female rats (Control Group) used as control were administered with pre-filtered water $(10 \mathrm{~mL} / \mathrm{kg})$. Animals were observed for clinical effects at $30 \mathrm{~min}$, hourly up to $4 \mathrm{hr}$, at $6 \mathrm{hr}$ post dosing and once daily up to day 14 . Their body weights were measured on day 1, 7 and at termination (day 14). Following euthanasia, gross necropsy was performed on both the Test Group and Control Group animals. Following the no-observable-adverseeffects-level (NOAEL) findings from the previously tested group (Test Group), three female rats (Continuing Test Group) were administered orally with $2000 \mathrm{mg} / \mathrm{kg}$ body weight of test substance in $10 \mathrm{~mL} / \mathrm{kg}$ vehicle pre-filtered water. Animals were observed for clinical effects at $30 \mathrm{~min}$, hourly up to $4 \mathrm{hr}$, and at $6 \mathrm{hr}$ post dosing and once daily up to day 2 . Their body weights were measured on day 1 and at termination (day 2). On day 2 the animals were sacrificed for necropsy. This study was performed in compliance with the appropriate provision of the OECD (2002), Test No. 423: Acute Oral toxicity Acute Toxic Class Method, OECD Guidelines for the Testing of Chemicals, Section 4, OECD Publishing, Paris (OECD, 2002). The procedures of use and care of animals were adhered to approval from Universiti Kebangsaan Malaysia's Animal Ethics Committee (BIOSERASI/UKM/2018/FAEZA/28JUNE/931-JUNE-2018-JUNE-2019). 


\section{Statistical Analysis}

All the data were presented as the mean \pm standard error of mean (SEM) in at least three independent experiments. Statistical analyses using analysis of variance (ANOVA) was conducted to assess the significance between means followed by a Dunnet's t-test. A $p$-value of $<0.05$ was considered significant.

\section{RESULTS AND DISCUSSION}

\section{Physical Characteristics of Refined PMFO}

The physical characteristics of refined PMFO is presented in Table 1. The oil was degummed, bleached and deacidified. The phytonutrient contents of refined PMFO are as follows: carotenes (1255 ppm), tocopherols and tocotrienols (1290 ppm), sterols (591 ppm) and squalene (886 ppm). The oil contains $7.79 \mathrm{~g} / 100 \mathrm{~g}$ DAG and $92.2 \mathrm{~g} / 100 \mathrm{~g}$ TAG. The fatty acid composition is similar to what have been reported for palm olein, which is predominantly high in palmitic acid (C16:0, 36.9 g/100 g) and oleic acid (43.5 g/100 g), with $10.6 \mathrm{~g} / 100 \mathrm{~g}$ linoleic acid (C18:2) (Teh and Lau, 2021). The present data is in line with what has been recently reported, where refined PMFO retains substantial amount of total

TABLE 1. PHYSICAL CHARACTERISTICS OF REFINED PALM-PRESSED MESOCARP FIBRE OIL ${ }^{1}$

\begin{tabular}{lc}
\hline Parameter & Weight \\
\hline Free fatty acids $(\mathrm{g} / 100 \mathrm{~g})$ & 0.2 \\
Fatty acid composition $(\mathrm{g} / 100 \mathrm{~g})$ & \\
C10:0 & 0.1 \\
C12:0 & 2.6 \\
C14:0 & 1.5 \\
C16:0 & 36.9 \\
C16:1 & 0.5 \\
C18:0 & 3.6 \\
C18:1 & 43.5 \\
C18:2 & 10.6 \\
C18:3 & 0.6 \\
C20:0 & 0.1 \\
Acylglycerol composition $(\mathrm{g} / 100 \mathrm{~g})$ & \\
Monoacylglycerol & \\
Diacylglycerol & \\
Triacylglycerols & 0.05 \\
Phytonutrients $(\mathrm{mg} / \mathrm{kg})$ & 7.79 \\
Carotenoids & 92.17 \\
Tocols & \\
Sterols & 2591 \\
Squalene & \\
\hline & \\
\hline
\end{tabular}

Note: ${ }^{1}$ Results are presented in means $\pm \mathrm{SE}$ of at least three separate experiments. carotene, vitamin E and sterols compared to PMFO (Teh and Lau, 2021). Notably, the concentration of phytonutrients are still substantially higher than that of CPO and commercially available red palm oil as reviewed in our published data (carotenoids, 600-750 ppm and tocols, 717-863 ppm) (Loganathan et al., 2017). This could be explained by the extraction methods, where refined PMFO used in the present study was extracted from pressed mesocarp using n-hexane while CPO was obtained by mechanical pressing of mesocarp. The high amount of carotenes and vitamin E in refined PMFO was due to its high content in the bi-membrane layer of the cell in the membrane and was co-extracted with the residual oil using n-hexane (Lau et al., 2006). The condition subjected to the extraction of $\mathrm{PMFO}$, in particular the deodorisation temperature (which is below $200^{\circ} \mathrm{C}$, as compared to conventional $\mathrm{CPO}$ deodorisation temperature at $265^{\circ} \mathrm{C}$ ), does not significantly degrade the phytonutrients. The extraction method however, did not modify the fatty acid composition of PMFO as compared to CPO.

\section{MTT Viability Assay}

The cytotoxic effects of refined PMFO against V79-4 fibroblast cells as assessed by MTT assay following $24 \mathrm{hr}$ treatment are shown in Figure 1. V79-4 cells showed decrease in viability in a concentration-dependent manner following $24 \mathrm{hr}$ treatment with refined PMFO. The results show that at the highest concentration of refined PMFO $(1 \% \mathrm{v} / \mathrm{v}),(72.65 \pm 4.1) \%$ of viable cells were observed (Figure 1). A concentration response effect was seen following treatment with $\mathrm{H}_{2} \mathrm{O}_{2}$ with an inhibitory concentration $\left(\mathrm{IC}_{50}\right)$ value of $1.568 \mathrm{mM}$. No $\mathrm{IC}_{50}$ values were observed for refined PMFO treated V79-4 cells as compared to positive control $\left(\mathrm{H}_{2} \mathrm{O}_{2}\right)$ (Figure 1). $\mathrm{H}_{2} \mathrm{O}_{2}$ was used to validate the experimental procedure. Based on the results obtained, refined PMFO has no cytotoxic effect using a widely acceptable method (MTT assay) in V79-4 fibroblast cells. Our group has previously studied the cytotoxicity of PMFO against three human cancer cell lines, namely Hep-G2, LS174T and SK-MEL-28, and no cytotoxic effect has been reported (Teh et al., 2021). The results were supported by a study conducted on cytotoxic effect oil palm kernel protein hydrolysates (OPKHs) against Hep-G2 cells where no cytotoxicity was observed. The growth simulation and prolongation of cells could occur due to the presence of oleic acids in OPKHs that also present in oil palm-based oil extracts (Chang et al. 2014). Other than that, this could also be possibly explained by the synergistic and antagonistic effects of the components in PMFO, which warrants further investigation. 
(a)

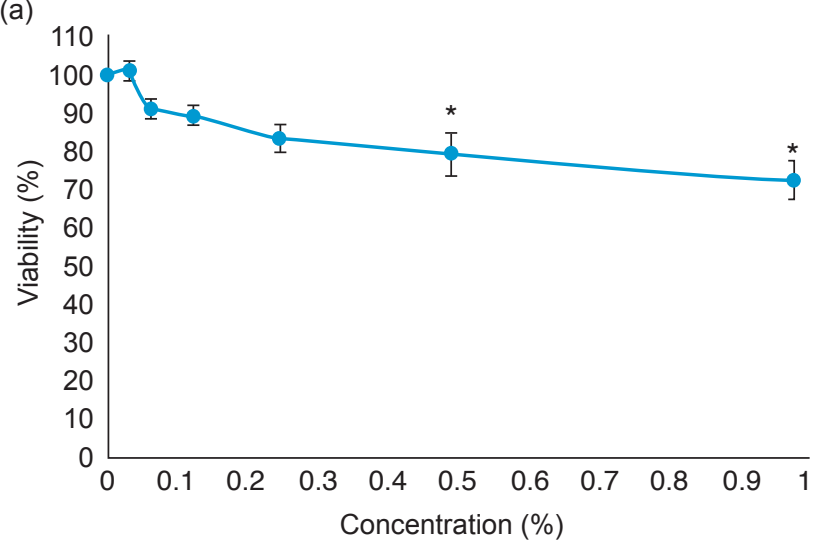

(b)

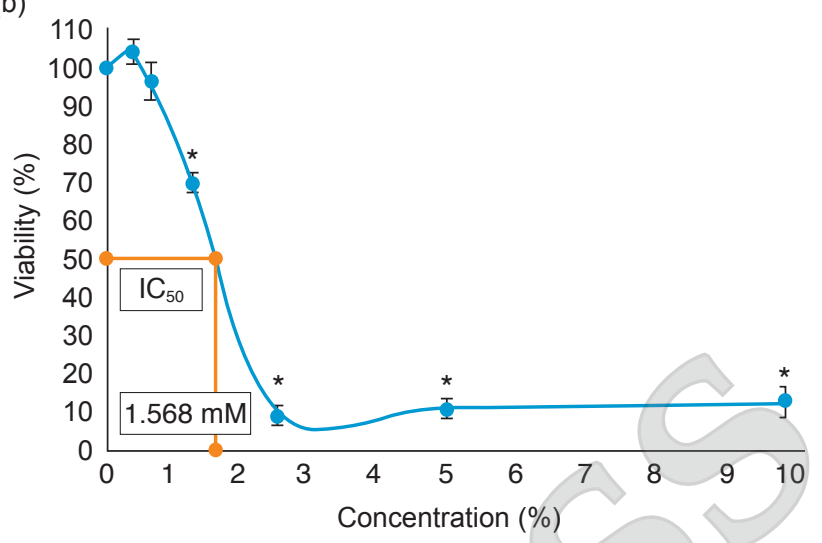

Note: ${ }^{1}$ The results are expressed as mean $\pm \mathrm{SE}$ of at least three independent experiment. * Significant difference $(p<0.05)$ as compared to negative control.

Figure 1. Cytotoxicity of (a) refined palm-pressed mesocarp fibre oil (PMFO), and (b) $\mathrm{H}_{2} \mathrm{O}_{2}$ against V79-4 cells with 24 hr of incubation.

\section{Alkaline Comet Assay}

The detection of primary DNA damage induced by refined PMFO in V79-4 cells was assessed by Alkaline Comet assay. Negative control cells displayed low levels of background damage. Scoring for the DNA damage was done based on TM values. As shown in Table 2, V79-4 negative control cells has TM of $(0.432 \pm 0.09)$. As shown in Table 2, there was a slight increase with no significant difference in $\mathrm{TM}$ at $\mathrm{IC}_{25},(0.468 \pm 0.09)$ of refined PMFO treated cells respectively at $24 \mathrm{hr}$ as compared to negative control cells. This data showed that refined PMFO has no capability to induce direct DNA strand breakage in V79-4 cells. A significant $(p<0.05)$ increase in DNA damage shown by TM was observed in $\mathrm{H}_{2} \mathrm{O}_{2}$ treatment at $1 \mathrm{mM}$, which served as positive control (Table 2). This data indicates that refined PMFO does not induce DNA damage, this may partly be explained by the fact that PMFO is the power house of antioxidants, with a recent published data from our group to support

TABLE 2. LEVEL OF DNA DAMAGE ON V79-4 TREATED CELL LINE WITH R REFINED PALM-PRESSED MESOCARP FIBRE OIL ${ }^{1}$

\begin{tabular}{lc}
\hline Item & $\begin{array}{c}\text { Level of DNA damage } \\
\text { (Arbitrary unit) }\end{array}$ \\
\hline Negative control & (TM) $24 \mathrm{hr}$ \\
Refined PMFO $\left(\mathrm{IC}_{10}\right)$ & $0.432 \pm 0.08$ \\
Refined PMFO $\left(\mathrm{IC}_{50}\right)$ & $0.343 \pm 0.04$ \\
& $0.468 \pm 0.09$ \\
Positive control $\left(\mathrm{H}_{2} \mathrm{O}_{2}\right)$ & (TM) 30 min \\
\hline
\end{tabular}

Note: ${ }^{1}$ The results are the means $\pm \mathrm{SE}$ of at least three separate experiments $\left({ }^{*} p<0.05\right.$ vs. negative control). PMFO - palmpressed mesocarp fibre oil; TM - tail moments. this (Teh et al., 2021). It has been reported that the bouquet of phytonutrients in PMFO has free radical scavenging effects as assessed using $\alpha, \alpha$-diphenyl$\beta$-picrylhydrazyl (DPPH), $\mathrm{H}_{2} \mathrm{O}_{2}$ and nitric oxide (NO) radicals scavenging assay when compared with extra virgin coconut oil and red palm oil (Teh et al., 2021). The presence of vitamin E, particularly tocotrienols and tocopherols, are known for their potent antioxidant activity. Moreover, carotenoids and co-enzyme Q10 are proven to scavenge $\mathrm{H}_{2} \mathrm{O}_{2}$ radicals effectively. A previous study also acknowledged the antioxidant capacity of the extracts of oil palm fruit through $\mathrm{H}_{2} \mathrm{O}_{2}$ scavenging assay (Balasundram et al., 2005). This finding further confirms that the oil palm-based edible oil, is rich in antioxidants that acts on radicals. Carotenoids and tocotrienols, the two most abundantly available antioxidants in PMFO have been reported to exert protective effects in various diseases using animal and human models as reviewed by our group (Fu et al., 2014; Loganathan et al., 2017).

\section{Acute Oral Toxicity}

There was no difference observed between female Sprague-Dawley rats treated with refined PMFO at $2000 \mathrm{mg} / \mathrm{kg}$ body weight and control (with $10 \mathrm{~mL} / \mathrm{kg}$ body weight of pre-filtered water) on the behavioural observations (over the 14-day interval). General clinical observations (namely skin and fur, eyes, respiratory effect, mucous membrane, motor activity, tremor, convulsion, walking behaviours, and diarrhoea) were normal for both treated and control animals (Table 3). No mortality or any toxic symptoms was observed. Furthermore, necropsy results including observations in all eight separate organs (namely brain, kidneys, lungs, liver, stomach, spleen, heart, and pancreas) showed no notable abnormalities. No significant differences in body weight were 
observed between rats treated with refined PMFO treatment and control (Figure 2). Percent of increment in rat's body weights for treated and control showed no significant difference. There was no remarkable difference in mean percentage of organ to animal body weight between rats treated with refined PMFO and control. The heart, kidneys, liver, lungs and spleens are the first organs to display metabolic responses to toxic substances. Organ weights are useful indicator of any kind of toxicity, in particular in drug administration. It is important to note that without further morphological changes in acute toxicity, differences in organ weight between treated and control animals may occur (Ara and Usmani, 2015). Taken together the data observed, the administration of refined PMFO does not exert acute oral toxicity impact in rats. This is in line with an extensive review published by our group on the toxicological and nutritional assessment of CPO and red palm oil (Loganathan et al. 2017). In addition, a study conducted in weanling Wistar/ NIN albino rats using CPO, refined palm oil and peanut oil has shown that the vegetable oils tested using a diet containing $10 \%$ dietary fat has no adverse effects on growth rate, feed efficiency, digestibility and fat absorption after a 90-day feeding period (Manorama and Rukmini, 1991).

\section{Limitations/Recommendations}

The method for refining and processing of PMFO varies between factories. Apart from that, diversity, degree of palm fruit ripeness and geographical location of plantation could also contribute to variation in the carotene concentration (Loganathan et al., 2017). In view of that, it is advisable to have a harmonised method and national standard specification for PMFO and refined PMFO to provide consistency in the nutritional properties.

TABLE 3. CLINICAL FEATURES OF THE TEST AND CONTROL ANIMALS DURING OBSERVATION PERIOD ${ }^{1}$

\begin{tabular}{|c|c|c|c|c|c|c|c|c|c|}
\hline \multirow{2}{*}{$\begin{array}{l}\text { Observation-post } \\
\text { dosing }\end{array}$} & \multicolumn{3}{|c|}{ Control group } & \multicolumn{3}{|c|}{ Test group } & \multicolumn{3}{|c|}{ Continuing test group $(2000 \mathrm{mg} / \mathrm{kg})$} \\
\hline & 1 & 2 & 3 & 1 & 2 & 3 & 1 & 2 & 3 \\
\hline Sex & F & F & F & F & F & F & $F$ & F & F \\
\hline Duration & A-K & A-K & A-K & A-K & A-K & A-K & A-K & A-K & A-K \\
\hline $30 \mathrm{~min}$ & 0 & 0 & 0 & 0 & 0 & 0 & 0 & 0 & 0 \\
\hline $1 \mathrm{hr}$ & 0 & 0 & 0 & 0 & 0 & 0 & 0 & 0 & 0 \\
\hline $2 \mathrm{hr}$ & 0 & 0 & 0 & 0 & 0 & 0 & 0 & 0 & 0 \\
\hline $3 \mathrm{hr}$ & 0 & 0 & 0 & 0 & 0 & 0 & 0 & 0 & 0 \\
\hline $4 \mathrm{hr}$ & 0 & 0 & 0 & 0 & 0 & 0 & 0 & 0 & 0 \\
\hline $6 \mathrm{hr}$ & 0 & 0 & 0 & 0 & 0 & 0 & 0 & 0 & 0 \\
\hline Day 2 & 0 & 0 & 0 & 0 & 0 & 0 & 0 & 0 & 0 \\
\hline Day 3 & & 0 & 0 & 0 & 0 & 0 & & & \\
\hline Day4 & 0 & 0 & 0 & 0 & 0 & 0 & & & \\
\hline Day 5 & 0 & 0 & 0 & 0 & 0 & 0 & & & \\
\hline Day 6 & 0 & 0 & 0 & 0 & 0 & 0 & & & \\
\hline Day 7 & 0 & 0 & 0 & 0 & 0 & 0 & & & \\
\hline Day 8 & 0 & 0 & 0 & 0 & 0 & 0 & & & \\
\hline Day 9 & 0 & 0 & 0 & 0 & 0 & 0 & & & \\
\hline Day 10 & 0 & 0 & 0 & 0 & 0 & 0 & & & \\
\hline Day 11 & 0 & 0 & 0 & 0 & 0 & 0 & & & \\
\hline Day 12 & 0 & 0 & 0 & 0 & 0 & 0 & & & \\
\hline Day 13 & 0 & 0 & 0 & 0 & 0 & 0 & & & \\
\hline Day 14 & 0 & 0 & 0 & 0 & 0 & 0 & & & \\
\hline
\end{tabular}

Note: ${ }^{1}$ For Test Group and Control Group, animals were observed for morbidity and mortality at 30 min, hourly up to 4 hr, at 6 hr post dosing and once daily up to day 14 . Continuing Test Group animals were observed at $30 \mathrm{~min}$, hourly up to $4 \mathrm{hr}$, at $6 \mathrm{hr}$ post dosing and at $24 \mathrm{hr}$. Alphabetical values (A - K) denote clinical changes observed and scored following treatment, with zero ("0") denoted as "normal" (A - fur and skin changes; B - eye changes; C - respiratory effect; D - mucous membrane; E - motor activity; F - tremor; $\mathrm{G}$ - convulsion; H - walking backwards or ataxia, inability to coordinate body movements; I - diarrhea; J - death; K - others). 

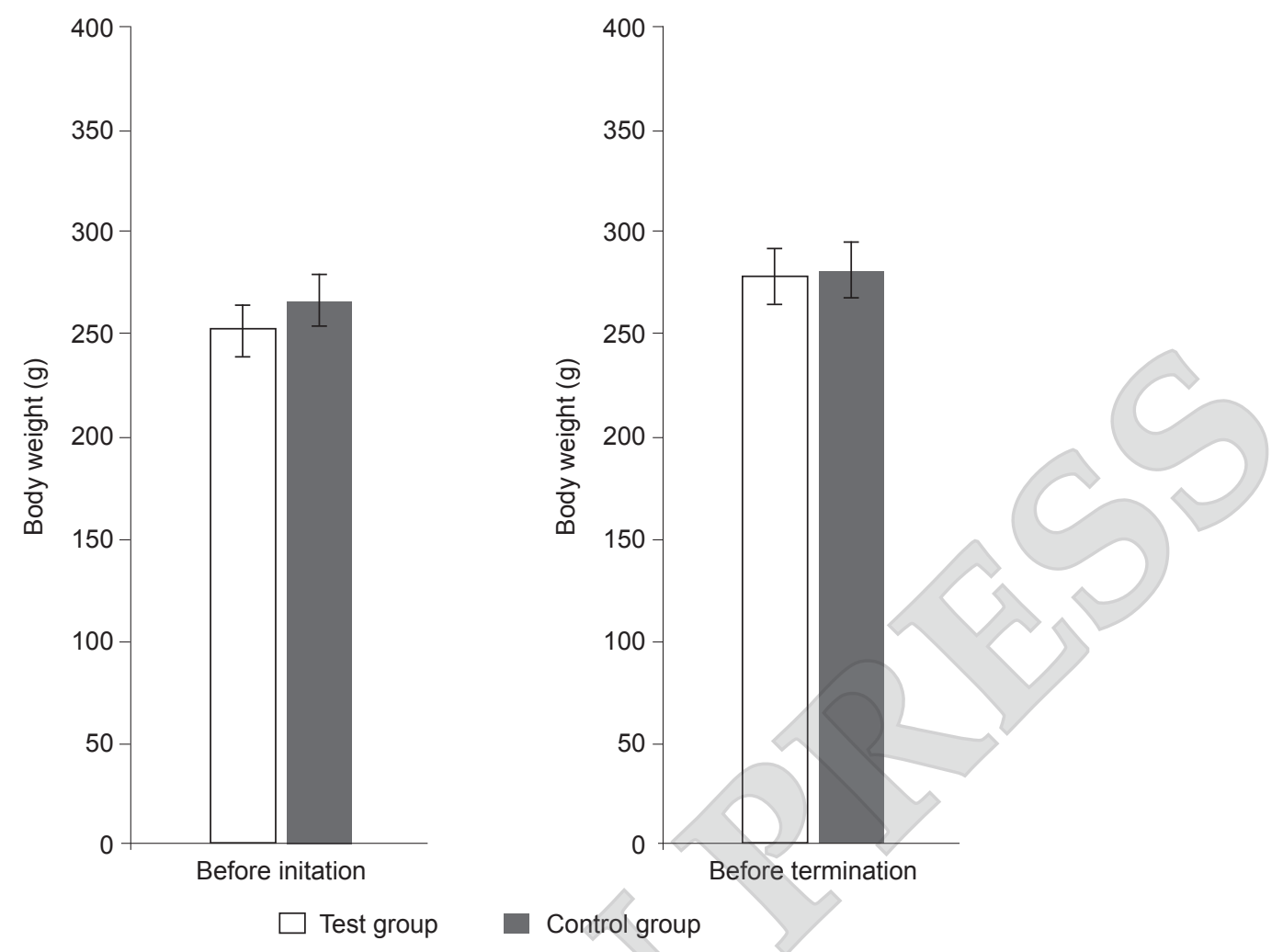

Note: ${ }^{1}$ results are expressed as mean $\pm \mathrm{SE}$ of at least three independent experiments.

${ }^{*}$ No significant difference $(p>0.05)$ was observed as compared to Control Group.

Figure 2. Mean body weight of Test Group and Control Group measured at two intervals of the study period.

\section{CONCLUSION}

Our toxicological assessment provides a preliminary finding on the safety usage of refined PMFO as a food component. Refined PMFO shows no cytotoxicity and did not cause any DNA damage in V79-4 cells. Acute toxicity animal testing has also shown no significant difference between groups treated. Based on toxicological study, refined PMFO showed noobserved-adverse-effect level (NOAEL) up to 2000 $\mathrm{mg} / \mathrm{kg}$ body weight of the animal. Further analysis may be needed to conduct more in-depth analysis on various aspects in relation to impact to health.

\section{ACKNOWLEDGEMENT}

The authors would like to thank the Director-General of MPOB, for providing the research grant that supported this study. We would also like to thank Kim Loong Palm Oil Mills Sdn. Bhd., Johor, Malaysia for providing the refined PMFO. The authors would also like to thank Ms. Mimi Norhilda and Ms. Noramiwati Rashid from Makmal Bioserasi, Centre for Research and Instrumentation Management (CRIM), University of Kebangsaan Malaysia for their excellent technical services on cytotoxicity, genotoxicity and acute oral toxicity studies.

\section{REFERENCES}

Abd Majid, R; Mohammad, A W and Choo, Y M (2012). Properties of residual palm pressed fibre oil. J. Oil Palm Res., 24: 1310-1317.

Ainie, K; Siew, W; Tan, Y A; Nor Aini, I; Mohtar, Y; Tang, T and Nuzul, A (2005). MPOB Test Methods. MPOB, Bangi, Selangor.

Ara, A and Usmani, J A (2015). Lead toxicity: A review. Interdiscip. Toxicol., 8: 55-64.

Awang, N; Ahlam, S N F and Chan, K M (2015). Cytotoxicity and genotoxicity assessments of Batik industrial wastewater on V79 cells. Toxicol Inter., 22(3): 76-82.

Ayeleso, A; Brooks, N and Oguntibeju, O (2014). Impact of dietary red palm oil (Elaeis guineensis) on liver architecture and antioxidant status in the blood and liver of male Wistar rats: Peered reviewed original articles. Med. Tech. SA., 27(2): 18-23.

Chang, S K; Hamajima, H; Amin, I; Yanagita, T; Mohd Esa, N and Baharuldin, M T H (2014). Cytotoxicity effect of oil palm (Elaeis guineensis) kernel protein hydrolysates. Int. Food Res. J., 21(3): 909-914. 
Choo, Y M; Yap, S C; Ooi, C K; Ma, A N; Goh, S H and Ong, A S H (1996). Recovered oil from palmpressed fibre: A good source of natural carotenoids, vitamin E, and sterols. J. Amer. Oil Chem. Soc., 73(5): 599-602.

Fu, J Y; Che, H L; Tan, D M Y and Teng, K T (2014). Bioavailabilities of tocotrienols: Evidence in human studies. Nutr. Metab. (Lond.), 11(1): 5.

Hasliyati, A; Rusnani, A M; Wan Hasamuddin, W H; Ng, M H; Nor Faizah, J and Rohaya, M H (2021). The effects of recylcing palm pressed fibre oil on crude palm oil quality. J. Oil Palm Res. DOI: 10.21894/jopr.2021.0016

Lau, H L N; Choo, Y M; Ma, A N and Chuah, C H (2006). Quality of residual oil from palm-pressed mesocarp fibre (Elaeis guineensis) using supercritical $\mathrm{CO} 2$ with and without ethanol. J. Amer. Oil Chem. Soc., 83(10): 893-898.

Loganathan Jr, R; Selvaduray, K; Nesaretnam, K and Radhakrishnan, A K (2010). Health promoting effects of phytonutrients found in palm oil. Malays. J. Nutr., 16(2): 309-322.

Loganathan, R;Subramaniam, KM; Radhakrishnan, A K; Choo, Y M and Teng, K T (2017). Healthpromoting effects of red palm oil: Evidence from animal and human studies. Nutr. Rev., 75(2):98-113.

Manorama, R and Rukmini, C (1991). Nutritional evaluation of crude palm oil in rats. Am. J. Clin. Nutr., 53(4): 1031S-1033S.

Manorama, R; Chinnasamy, $\mathrm{N}$ and Rukmini, C (1993a). Effect of red palm oil on some hepatic drug-metabolizing enzymes in rats. Food Chem. Toxicol., 31(8): 583-588.

Manorama, R; Chinnasamy, N and Rukmini, C (1993b). Multigeneration studies on red palm oil, and on hydrogenated vegetable oil containing mahua oil. Food Chem Toxicol., 31(5): 369-375.

Manorama, R; Harishankar, N; Polasa, K and Rukmini, C (1989). Mutagenicity studies on repeatedly heated crude and refined palm oil. J. Oil Tech. Assoc. India., 21(2): 29-31.

Mosmann, T (1983). Rapid colorimetric assay for cellular growth and survival: Application to proliferation and cytotoxicity assays. J. Immunol. Methods., 65(1-2): 55-63.

Nang Lau, H L ; Puah, C W; Choo, Y M; Ma, A N and Chuah, C H (2005). Simultaneous quantification of free fatty acids, free sterols, squalene, and acylglycerol molecular species in palm oil by hightemperature gas chromatography-flame ionization detection. Lipids, 40(5): 523-528.

Neoh, B K; Thang, Y M; Zain, M Z M and Junaidi, A (2011). Palm pressed fibre oil: A new opportunity for premium hardstock? Int. Food Res. J., 18(2): 769-773.

Noorshamsiana, A W; Astimar, A A; Iberahim, N I; Nor Faizah, J; Anis, M; Hamid, F A and Kamarudin, $H$ (2017). The quality of oil extracted from palm pressed fibre using aqueous enzymatic treatment. J. Oil Palm Res., 29(4): 588-593.

Obibuzor, J U; Okogbenin, E A and Abigor, R D (2012). Oil recovery from palm fruits and palm kernel. Palm Oil., 299-328.

OECD (2002). Test No. 423: Acute oral toxicity Acute toxic class method. OECD Guidelines for the Testing of Chemicals. OECD Publishing, Paris. https: / / www.oecd-ilibrary.org / environment / test-no-423-acute-oral-toxicity-acute-toxic-classmethod_9789264071001-en.

Putra, N R; Wibobo, A G; Machmudah, S and Winardi, S (2019). Recovery of valuable compounds from palm-pressed fibre by using supercritical $\mathrm{CO}_{2}$ assisted by ethanol: Modeling and optimization. Sep. Sci. Technol., 55(17): 3126-3139.

Siew, E L; Farris, A F; Rashid, N; Chan, K M and Rajab, N F (2020). In vitro toxicological assessment of gadolinium (III) chloride in V79-4 fibroblasts for classification of health hazard. Genes Environ., 42: 22.

Subramaniam, V; Menon, N R; Sin, H and May, C Y (2013). The development of a residual oil recovery system to increase the revenue of a palm oil mill. J. Oil Palm Res., 25(1): 116-122.

Sulihatimarsyila, A N; Lau, H L N; Nabilah, K M and Azreena, I N (2019). Refining process for production of refined palm-pressed fibre oil. Ind. Crops Prod., 129: 488-494.

Sulihatimarsyila, A N; Lau, H L N; Nabilah, K and Azreena, I N (2020). Production of refined red palm-pressed fibre oil from physical refining pilot plant. Case Stud. Chem. Environ. Eng., 2: 100035.

Teh, S S; Lau, H L N and Mah, S H (2019). Palmpressed mesocarp fibre oil as an alternative carrier oil in emulsion. J. Oleo Sci., 68(8): 803-808.

Teh, S S and Lau, H L N (2021). Quality assessment of refined red palm-pressed mesocarp olein. Food Chem., 340: 127912. 
Teh, S S; Mah, S H; Lau, H L N; Teng, K T and Loganathan, R (2021). Antioxidant potential of red palm-pressed mesocarp olein. J. Oleo Sci. 70(12): 1719-1729.
Tice, R R; Agurell, E; Anderson, D; Burlinson, B; Hartmann, A; Kobayashi, H; Miyamae, Y; Rojas, E; Ryu, J C and Sasaki, Y F (2000). Single cell gel / comet assay: Guidelines for in vitro and in vivo genetic toxicology testing. Environ. Mol. Mutagen., 35(3): 206-221. 